\title{
PUTINIZATION AND NEO-CONTAINMENT
}

\author{
George Anglițoiu \\ National University of Political Studies and Public Administration/SNSPA \\ Department of International Relations and European Integration \\ Bucharest, Romania \\ george@anglitoiu.ro
}

\begin{abstract}
The Western strategic vision about the East lies at a crossroads. Similar to the Interwar Era, when acts of unilateralism in foreign affairs and aggression by the revisionist powers under popular but militaristic leaders have triggered the outbreak of World War II, the West seems unable to act coesively and decidedly to counter the contestation of international law and order.

Therefore, a better understanding of the past lessons and negative impact of the "functionalist" spillover of power personification is at stake.

\section{Keywords}

Cyber-Espionage, Demokratura, European Neighbourhood Policy, Fake News, Frozen Wars 2.0, NATO's Cat Syndrome, Neo-containment, New Cold War, Putinization
\end{abstract}

\section{INTRODUCTION}

If Platon, so familiar with the hybris of tyrants, had become acquainted with the incumbent head of Russian Federation, he would have tasked his main character Socrates to start his maieutics approach with the basic question: What is Putinization? And then, an Alcibiades of the symposium would have not replied, 
"an autocratic and abusive form of national and international leadership based on the idiosyncratic charisma of Russian President Vladimir Putin and aiming to restore at least and at last the imperial grandeur and status of the Kremlin-based state".

Theatrics aside, Putinization is similar to Erdoganization, Trumpization and other demokratura-like powerplays, but more effective due to the Imperial imaginative mix of Orthodox Tsarism and Secular Communism. More comprehensive and impactful than Putinism ${ }^{1}$ due to the spillover effects of reorganizing societal preferences, domestic politics and foreign affairs in accordance with the vision, will and acts of one man, namely the chosen/expected one. Putinism is about dominance by Kremlin and submission to its leader, while Putinization also generates mimetism, emulation among wannabees and challenges to already established democracies.

On the other hand, Neo-containment means a revival of George Kennan's recipe for stoping subversion generated by Kremlin's insatiable geostrategic hunger. Putin is less prone to mass violations of human rights as in the case of persecutions, deportations and exterminations promoted by Stalin, but is nonetheless autocratic in vision or disrespect for democratic values and rule of international law. The enigmatic death of Stalin and the (bloody) power-struggle which followed it could be a scenario for the evolution of Kremlin when Putin will grow older and weaker in his physical attributes if Eltin's lesson is to be compehended it. In the end, the triumph of Putinization lies in the successful transition to a new and effective Putin-like pupil who currently is missing from Soljenitin's first circle of power.

${ }^{1}$ In this author's view, Viktor Orbán is not a Putinist but a political subject to Putinization. Despite his acts of illiberarism and constant opposition to EU deepening, he has not given patronage to political killings and secessionist guerillas. For the opposite definition of Putinism and view on its offsprings, see Zakaria (2014) and Oliker (2017). 


\section{EU AND NATO CONFRONTING REACTION}

When the European Neighbourhood Policy (ENP) was set up 15 years ago, it was designed for creating a "ring of friends" (Prodi, 2003) all around EU, but especially to the East and the South. Meanwhile, ENP has evolved into an extension of the Foreign Affairs and Security Policy (FASP) with two components: the Eastern Partnership and the Union for the Mediterranean.

Enlargement or Partnership represents a key dilemma for the EU future because in the end is all about where and how to stop best the expansion process. Therefore, the frontier security becomes quintessential to Europeanization success if close attention is paid to historical failures - e.g. the Roman Empire waging centuriesold wars of attrition against Persia, but collapsing under the pressure of Germanic tribes. The Roman strategic concept of "foederati" (meaning allies in the neighbourhood / proximity of the "limites") had its benefits for several centuries until either the proxies succumbed to new, more ambitious comers, or Rome was subject to almost continuos imperial infighting.

The Enlargement choice cannot be doable as a never-ending story. It is a bad scenario and EU should focus on deepening and less on "bringing and blending in".

EU has already several candidate countries in the Western Balkans enrolled in the negotiation process (Serbia, Montenegro ${ }^{1}$, Northern Macedonia), plus the cronic Turkish dilemma, and has nonetheless acknowledged by the Juncker Moratorium the difficulties of taking in new members (still bound to a burdening yugoslav past).

1 A NATO member since June 2017, Montenegro was confronted with an alleged coup d'état plot with Russian involvement on the occasion of 2016 parliamentary elections. See the proceedings of the judicial case (started in September 2017) and the study of Bajrović, Garčević and Kramer (2018).

The episode is noteworthy for showcasing, similarly to Serbia and Northern Macedonia, the difficulties of full-fledged Western commitment for countries with significant historical, political and economical ties with Russia. 
EU cannot expand in hot or frozen-wars areas (Ukraine, Republic of Moldova, Georgia, Armenia, Azerbaidjan) which means that 6 out of 6 countries of the Eastern Partnership (2009) are strategically ineligible.

The Partnership choice instead is strategically wiser taking into account its end goal: to replicate the EU success story in a complex, troublesome area inside the Russian "sphere of influence". The catalogue of requirements for such an accomplishment is by no means easy to achieve:

1. To adequate "more for more" financing in order to strengthen democracy or its increments;

2. To use smart diplomacy to counter Russian hostile propaganda;

3. To have the resolve to use hard power when needed.

\section{THE RUSSIAN FACTOR}

Under the aegis of Putinization, Russia is entitled to authoritarian and enlighten leadership in both domestic politics and foreign policy (in the neighbourhood). In fact, for Aleksandr Dugin ${ }^{1}$ and other Eurasian/statist theorists, The Near Abroad is Russian-bound territory too, lost temporarily due to Western schemeful policy. Thus, Motherland under siege becomes once more the main topic of internal propaganda, coupled with the moral assertion that Russia has never waged offensive wars. But rigourous historical analysis (e.g. the 1799 Suvorov expedition in the Alps or the 1939/1940 Winter War against Finland or the 1979 Invasion of Afghanistan) is clearly underlining the true content of this Fake news silogism.

Putinization needs and is fueled by foreign success. The annexation of Crimeea and the constant challenges to the integrity and sovereignity of the rest of Ukraine, Republic of Moldova or Georgia represent necessary reparatory acts in the Near Abroad, designed to restore the honor ${ }^{2}$ of Russia, at regional level at

1 For an analysis of Dugin's masterwork (1997), see Dunlop (2014). For a review of Dugin's latest work, Last War of the World-Island (2015), see Cucută (2015).

2 For a chronology of the pervasiveness of "honor" in Russian strategic thinking, see Tsygankov (2012). 
least. The military outposts in Syria and the backing of the genocidal (in the Western eyes) Assad regime show the signs of revival of Imperial grandeur at large, which has come a long way since the first display of Putin's and his aides ${ }^{1}$ foreign ambitions, manifest in the occupation of Pristina Airport in June 1999 and the ensuing standoff with NATO forces ${ }^{2}$. Fast forward through his four terms as president and one as prime-minister, and the reader will find a willing Putin capable of staging democracy lessons for the West, inspire anti-EU mimetism in some European capitals not so long ago subject to armored divisions teachings of "limited sovereignity", and shadowing more or less successful killing atempts against political opponents, journalists and former allies turned rogue. But despite an over-reaching control of the media, investment in the security sector and territorial accruement, in the end it all depends on the will to wage frontal war against the (perceived) hegemonic enemy. But the record of Russia's first moves at global level is not that encouraging if you take into consideration Austerlitz 1805, Tsushima 1905 or Cuba 1962. Far better achievements has Russia registered as target of full-scale invasion, but even in this category, the only conflict of such scale against Western democracies has been at Sebastopol in 1854-55 and with a significantly negative outcome, both militarily and strategically.

In terms of militarization, Putin's Russia has even followed suit of the American example of allegedly using private armies ${ }^{3}$ on different battlefields relevant to Kremlin (Crimea, secessionist republics of Luhansk and Donetsk, Lybia, Sudan etc.) but with less success when pitted against more versatile, air-superior and battle-hardened American units.

1 At that time, Putin acted as the Secretary of Security Council of Russian Federation and his future-to-be Assistant on Foreign Affairs and Deputy Prime-Minister, Sergei Prikhodko, was Deputy Head of the Presidential Administration.

2 See the report of Mintier, Harrigan, Clancy, Amanpour and Burns (1999).

${ }^{3}$ For the profile of ChVKVagner, one of the Russian most prominent private contractor agencies, and its ties to Kremlin, see Taylor (2018) or Khazov-Cassia and Coalson (2018). 


\section{THE TURKISH FACTOR}

Erdoganization is a similar but also competing leadership project to Putinization, meaning the restoration of Ottoman Empire as leader of the Islamic World. Prior to AKP regime, Turkey had already had a NATO troublesome membership: big contributor (no. 4) but sharing a long-standing rivalry with Greece over Cyprus and the Aegean Islands. Moreover, the algorithm for AKP European affairs policy has been two-folded: primo, compliance to the Copenhagen accession criteria in order to bring under control the army (the former guardians of the Republic) on the basis of the imperative of implementing civilian control over the security sector; secundo, learning from the mistakes of past Islamist parties led by Necmettin Erbakan, the splinter AKP promoted a slow Islamization of Turkey based on incremental measures contrary to EU membership. Thus, a delayed accession into EU translated into less commitment to EU values and policies, including ENP.

The direct US-Turkey relationship has also been eroded in the context of Syrian war and fight against ISIS. Lenient at first to ISIS, the AKP regime has been permisive to Jihadist-bound fighters to use Turkish assets, and turning also a blind eye to their illegal exports of oil from the fields fallen under their control. Only when the ISIS excesses and zeal in the hunt against Kurdish resistance started to trespass into Turkish core territory (e.g. the 2016 Istanbul Airport bombing), AKP was forced (for the sake of showing a display of fortitude and efficiency) to take coercive measures against it. Until then, it had been memorable the pasive stance of Turkish armoured forces watching closely, from a few kilometres radius, the 112 days - brave resistance of Kurdish besieged population of Kobani. Previously, Turkey ${ }^{1}$ had chosen not to grant air space to US aviation, nor to join the ad-hoc coalition against ISIS. ${ }^{2}$

${ }^{1}$ For the opposite view, see the arguments of The Guardian's editorial of October 8, 2014.

2 For the details of Kobani siege and the crucial role played by US airstrikes in curbing the ISIS offensive, see Grant (2018). 
In the end, it turned out to be an opportunistic strategic gain for the AKP regime to wait and then decide to invade the Syrian Ifrin ${ }^{1}$ and defeat the victorous, but weakened Pershmerga fighters, de facto but in vain allied with the ally of Turkey, USA.

In fact, the Syrian civil war has evolved into an almost perfect and anarchic Hobbes-ian bellum omnium contra omnes, with Putin's Russia being allied to the Assad regime against Free Syrian Army allied with Erdogan's Turkey against Kurdish forces allied with USA and its coalition against an ISIS waging holy war against all the aforementioned.

The November 2015 dogfight $^{2}$ had already shown how easy is to trigger regional violence by swift escalation of tensions in the context of reciprocal propension to provocation and state honor defence under the leadeship of tsar and sultan in-themaking Putin and Erdogan.

In conclusion, Erdoganization imitates and also "emulates" Putinization, ending up being both domestically and internationally a grave factor of concern despite its rhetorics of "zero problems with neighbours" leading in fact to "zero neighbours with no problems" (to use the coinage of Turkish dwindling free opposition press).

\section{The Frozen Wars}

Used as hard power tools to deny full sovereignty to former USSR states and satellites (Republic of Moldova, Georgia, Armenia, Azerbaidjan) in the post-Cold War Era, the frozen wars have become the norm in the proximity of the EU and Euro-Atlantic frontiers. The Russian Federation has recognized the claims for independence of some of the secessionist territories (Abhazia and South Ossetia) while the EU has been only a minor actor in the peace-making and nationbuilding processes.

${ }^{1}$ For the list of hundreds of civilian casualties caused by the Operation Olive Branch see The Syrian Observatory of Human Rights as quoted by Hacaoglu (2018).

2 For details of the first incident of a NATO country shooting down a Russian airplane since the '50s, see BBC (2015). For the rhetorics of full compliance to rules and regulations on both sides, see also Galeotti (2015). 
The Ukrainian crisis could be evaluated as a test for the 2.0 version of what a frozen war should look like. Started as a hot and strong reaction by already armed and combat trained patriotic vigilantes in the context of a treacherous Euromaidan planned as a Western gross interference into Rusland, this crisis represents the first manifestation of Russian direct annexation of a former territory, centered around the strategic naval base of Sebastopol. The recent announcement of surface-to-air missile deployment in Crimea ${ }^{1}$ only adds to the confirmation that despite international protests and sanctions, Putinization cannot be subject to Inter-war-like appeasement by collective security means.

\section{THE INCEPTION OF A NEW COLD WAR}

Centered on a charismatic person as panaceum of political performance, Putinization clashes with Westernization (meaning Americanization plus Europeanization) for the hearts, minds and resources of the Eastern and Central Europe. The classic Cold War ended when Kremlin was no longer able to cope with the burden of competing with the economic and military complex of the West, all these while being under the spell of NATO's cat syndrome. Despite the fact that NATO still has a weak article 5 common defence commitment, USSR never had "the curiosity" of a cartoon cat to see how USA would really play in the field the sentence "as it deems necessary" in case of agression.

Article 5 represents the real and crouching enemy for Putinization both within and outside the boundaries of Euro-Atlanticism. Thus, the need at Kremlin for false propaganda to persuade Slavic (-speaking) populations about the joint NATO-EU subversion, and the imperative for a new Russian enhanced race of armaments in order to cope with the militarization of the Baltic states, Poland, Romania and Bulgaria.

In this context, we have to mention the importance of Revolution in Military Affairs (RMA - meaning the extensive use of unmanned robotics and other hi-

1 See The Moscow Times (2018). 
tech capabilities on the battlefields) and speak about rival RMAs: Russia versus USA plus EU. Espionage alike is enjoying a new ${ }^{1}$, cyber-age with the 2006 cyberattack on Estonia leading to the response of creation by NATO of its Cyberintelligence Center in Tallinn. The corolary is Cyber-Putinization, which according to its patronymic ${ }^{2}$ is served by patriotic minds and souls eager to defend Russia free-willingly. While some experts have rushed in and call it "hybrid war", for a keen observer of history there is nothing new about it, but just the old school of subversion? . By electoral meddling and dissemination of "fake news" with covert funds, secured via obscure, organized-crime methods like laundromat ${ }^{4}$ (e.g. the embezzlement of 1 billion euro in the banking system of Republic of Moldova), Putinization has managed to get a foothold into inner fabrics of Western democracies ${ }^{5}$ to the very detrimetriment of security, trust and cooperation on both sides of the Atlantic.

Despite Putin's counter-project of Euro-Asian Union mirroing and targeting ENP, EU is expert in rhetorics but constantly falling behind in action. EU has no option but to compete with Putinization and a redesign of its toolkit is necessary in order to achieve Neo-containment. It shoud be based on clearer vision, single and stronger voice, Carrot and stick policy when dealing with the opponents of ENP, bigger financial support to help the EU-linked local entrepreneurship in ENP countries, and focus on EUBAM-like missions in order to enhace statehood in almost failed countries like Ukraine and Moldova. The division of labour between EU and NATO is still secured on the basis of the Berlin plus agreement

1 See the speech delivered by the head of MI6, Alex Younger, at St Andrews University (2018).

2 Apud McKirdy and Ilyushina, (2017).

3 See for instance the archival data documenting the "revolt of Tatar-Bunar" and proclamation of Soviet Republic of Moldova (1924), or the Western-spread activity of "Bessarabian societies", as quoted by Watts (2010).

4 See the investigations led by the Organised Crime and Corruption Reporting Project on the topic of Moldova Laundromat: https://www.occrp.org/en/component/tags/tag/moldova-laundromat

${ }^{5}$ For the Russian interference in the 2016 US Elections, see BBC (2018) and CNN (2018).

For an overview of Russian involvement in key recent political events in Europe, see Noah (2018). 
of 2002, and the re-envisioned European army, although affected by Brexit ${ }^{1}$-like developments, constitutes a relevant project as long as it entails stronger financial commitment to defence by the leading EU member-states and not conjectural rivalry to USA under provocative, but unsubstantial leaders like Trump.

But the leadership fraternity between Trump and Putin has already proved damaging to Euro-Atlanticism, and the weakend domestic stance of President Macron and Chancellor Merkel under the pressure of electoral dissatisfaction has lowered the importance of Franco-German dual-engine in leading a unified EU front.

Therefore, the fate of Neo-containment will much depend on the capacity of both NATO and EU elites to continue institutionalizing functional ties between West and East while waiting for a next generation of leaders to assume the responsibility of not abandoning through isolationism the unique benefits of $70+$ years of peace and prosperity by liberal means.

\section{REFERENCES}

- ***. 2014. "Turkey has good reasons for caution”. The Guardian. Wed. 8 Oct., 19.41 BST.

https://www.theguardian.com/commentisfree/2014/oct/08/guardianview-battle-kobani-turkey-good-reasons-caution.

1 The most important security paradox of Brexit lies in the very nature of Western interlocked defence architecture: if Russia would attack for a second time Finland, despite its neutrality, then the European Council could activate the mutual assistance clause embedded in the Lisbon Treaty [article 42(7), "inherited" from the WEU Treaty], leading afterwards, in accordance to the evolution of hostilities on the hypothetical battlefields, to an activation by the North Atlantic Council of article 5 at the request of European states with dual membership. Thus, not only United States and Canada, but also United Kingdom, will have to defend the very supranational entity it left behind in order to have full control of its sovereign strategic options... 
- ***. 2015. "Turkey's downing of Russian warplane - what we know". BBC News, 1 December, https://www.bbc.com/news/world-middle-east34912581.

- ***. 2018. "Russia Announces New S-400 Missiles Deployment in Crimea Amid Ukraine Naval Standoff". The Moscow Times. Nov. 28. https://themoscowtimes.com/news/russia-announces-new-s400-missilesdeployement-crimea-amid-ukraine-naval-standoff-63629.

- ***. 2018. "Russia-Trump inquiry: Full text of Mueller's indictment". BBC News. 16 February. https://www.bbc.com/news/world-us-canada43091945.

- ***. 2018. "Indicment in the United States District Court for the District of Columbia". CNN. Jul. 13. http://cdn.cnn.com/cnn/2018/images/07/13/gru.indictment.pdf.

- Bajrović, Reuf. Garčević, Vesko. Kramer, Richard. 2018. Hanging by a Thread: Russia's Policy of Destabilization in Montenegro. Russia Foreign Policy Papers. Foreign Policy Research Institute. June. https://www.fpri.org/wpcontent/uploads/2018/07/kraemer-rfp5.pdf

- Cucută, Radu. 2015. "Flogging the Geopolitical Horse". Europolity (9:1). pp. 227-233.

- Dunlop, John B. 2004. "Aleksandr Dugin's Foundations of Geopolitics". Demokratizatsiya (12:1). George Washington University. pp. 41-56.

- Galeotti, Mark. 2015. "Why did it take Turkey just 17 seconds to shoot down Russian jet?". The Guardian. Thu 26 Nov, 13.18 GMT. https:// www.theguardian.com/world/2015/nov/26/russia-turkey-jetmark-galeotti.

- Grant, Rebecca. „The Siege of Kobani”. 2018. Air Force Magazine, October. http://www.airforcemag.com/MagazineArchive/Pages/2018/October $\% 20$ 2018/The-Siege-of-Kobani.aspx.

- Hacaoglu, Selcan. 2018. "Turkey Captures Syrian Town of Afrin From Kurds". Bloomberg. March 18, 8:41 AM https://www.bloomberg.com/news/articles/2018-03-18/turkish-troopssyria-rebels-enter-kurdish-stronghold-in-syria.

- Khazov-Cassia, Sergei. Coalson, Robert. 2018. "Russian Mercenaries: Vagner Commanders Describe Life Inside The 'Meat Grinder'", Radio Free Europe / Radio Liberty. March 14, 21:06 GMT. https://www.rferl.org/a/russianmercenaries-vagner-commanders-syria/29100402.html. 
- McKirdy, Euan. Ilyushina, Mary. 2017. "Putin: 'Patriotic' Russian hackers may have targeted US election". CNN. Updated 2328 GMT (0728 HKT) June 2. https://edition.cnn.com/2017/06/01/politics/russia-putin-hackerselection/index.html.

- Mintier, Tom. Harrigan, Steve. Clancy, Jim. Amanpour, Christiane. Burns, Chris. 1999. "Russian troops block NATO forces at Pristina checkpoint". CNN. June 13.

http://edition.cnn.com/WORLD/europe/9906/13/kosovo.01/.

- Noah, Rick. 2018. "Everything we know so far about Russian election meddling in Europe". The Washington Post. January10. https://www.washingtonpost.com/news/worldviews/wp/2018/01/10/ev erything-we-know-so-far-about-russian-election-meddling-ineurope $/$ ?noredirect $=$ on\&utm_term $=.7802$ bbe9441a.

- Oliker, Olga. 2017. "Putinism, Populism and the Defence of Liberal Democracy". Survival (59:1). pp. 7-14.

- Taylor, Adam. 2018. "What we know about the shadowy Russian mercenary firm behind an attack on U.S. troops in Syria". The Washington Post. February 23.

https://www.washingtonpost.com/news/worldviews/wp/2018/02/23/w hat-we-know-about-the-shadowy-russian-mercenary-firm-behind-the-attackon-u-s-troops-in-syria/?utm_term $=.931$ b29009163.

- Tsygankov, Aleksandr. 2012. Russia and the West from Alexander to Putin: Honor in International Relations. Cambridge: Cambridge University Press.

- Watts, Larry. 2010. With Friends Like These... The Soviet's Bloc Clandestine War Against Romania. Volume I. Bucharest: Military Publishing House.

- Younger, Alex. 2018. 'Fourth Generation Espionage' - Fusing Traditional Human Skills With Innovation. Speech at St Andrews University. December 3. https://www.sis.gov.uk/news/alex-younger-st-andrews-speech.html.

- Zakaria, Fareed. 2014. “The Rise of Putinism”. The Washington Post. July 31. https://www.washingtonpost.com/opinions/fareed-zakaria-the-rise-ofputinism/2014/07/31/2c9711d6-18e7-11e4-9e3b7f2f110c6265_story.html?utm_term=.a17da8f6a9e7. 